\title{
Correction to: A fuzzy approach for the estimation of foreign investment risk based on values of rating indices
}

\author{
Simona Hašková ${ }^{1}$. Petr Fiala ${ }^{2}$
}

Published online: 16 April 2019

(C) Springer Nature Limited 2019

\section{Correction to: Risk Management https://doi.org/10.1057/s41283-019-00051-1}

Unfortunately, an incorrect grant number has been published. Please find the correct grant number here: [University of Economics, Prague] under Grant [IGA F4/66/2019]

Acknowledgement This work was supported by the [University of Economics, Prague] under Grant [number IGA F4/66/2019].

The original article can be found online at https://doi.org/10.1057/s41283-019-00051-1.

\section{Simona Hašková}

haskovas@post.cz

Petr Fiala

pfiala@vse.cz

1 Institute of Technology and Business in České Budějovice, Okružní 517/10, 37001 České Budějovice, Czech Republic

2 University of Economics, Prague, Nám. W. Churchilla 4, 13067 Prague 3, Czech Republic 